\title{
Tradisi Kearifan Lokal Minangkabau "Manjujai" untuk Stimulasi Perkembangan Anak Usia Dini
}

\author{
Asfi Yanti We ${ }^{1 凶}$, Puji Yanti Fauziah ${ }^{2}$ \\ Pendidikan Anak Usia Dini, Universitas Negeri Yogyakarta(1) \\ Pendidikan Luar Sekolah, Universitas Negeri Yogyakarta(2) \\ DOI: $\underline{10.31004 / \text { obsesi.v5i2.660 }}$
}

\begin{abstract}
Abstrak
Manjujai merupakan bentuk stimulasi berupa nyanyian, syair, atau kata dengan nilai-nilai kebaikan. Pemberian stimulasi menjadi faktor penting dalam mencapai perkembangan anak usia dini secara optimal sesuai dengan tahapan usia. Penelitian ini merupakan salah satu stimulasi perkembangan yang dapat diberikan kepada anak usia dini. Tujuan penelitian ini adalah untuk mengetahui pengaruh tradisi kearifan budaya lokal Minangkabau "manjujai" terhadap perkembangan anak usia dini. Penelitian menggunakan Library research melalui 6 langkah yaitu penentuan topik penelitian, tinjauan literatur terkini, reduksi literatur, pengorganisasian literatur, review literatur, dan pengambilan kesimpulan. Teknik analisis data berupa kualitatif deskriptif dengan menelaah beberapa literatur sekunder antara lain yaitu ebook, jurnal ilmiah Nasional dan Internasional, dan artikel yang berkaitan dengan manjujai pada anak. Hasil penelitian menunjukkan bahwa tradisi manjujai bukan hanya digunakan untuk menstimulasi satu aspek perkembangan saja namun dapat digunakan dibeberapa aspek perkembangan anak usia dini seperti kognitif, bahasa, motorik, sosial-emosional dan moral spiritual.
\end{abstract}

Kata Kunci: manjujai ; local wisdom; stimulasi aud

\begin{abstract}
Manjujai is a stimulation of songs, poems, or words of virtue. Stimulation is an important factor in achieving an optimal early age according to age stages. This research is a form of developmental stimulation that can be given to early childhood. The purpose of this study was to see the influence of the local wisdom tradition of Minangkabau "manjujai" on early childhood development. This research uses library research through 6 steps to determine the research topic, review the latest literature, reduce literature, organize literature, review literature, and collect literature. The data analysis technique is descriptive qualitative by examining several secondary literatures, including e-books, national and international scientific journals, and articles related to child manjujai. The results show that the manjujai tradition is not only used to stimulate one aspect of development but can be used in several aspects of early childhood development such as cognitive, language, motor, social-emotional and moral-spiritual.
\end{abstract}

Keywords: manjujai; local wisdom; early childhood stimulation

Copyright (c) 2020 Asfi Yanti We, Puji Yanti Fauziah

$\triangle$ Corresponding author:

Email Address : asfiyanti.2019@student.uny.ac.id (Koto Malintang, Balai Panjang, Kecamatan Lareh

Sago Halaban, Kabupaten Lima Puluh Kota, Sumatera Barat, Indonesia)

Received 10 July 2020, Accepted 11 November 2020, Published 16 November 2020 


\section{PENDAHULUAN}

Anak usia dini adalah anak dengan rentang usia 0-6 tahun (Undang-Undang Nomor 20 Tahun 2003 Tentang Sistem Pendidikan Nasional Pasal 1, Butir 14, 2003). Pada masa ini disebut juga masa peka dalam kehidupan seseorang. Periode ini merupakan tahap perkembangan awal individu yang menentukan sikap, nilai, perilaku, dan kepribadian individu di masa yang akan datang (Hurlock, 2013; Papalia et al., 2008). Hal tersebut menunjukkan bahwa tumbuh kembang anak harus sesuai dengan aturannya. Selain itu masa ini juga disebut dengan masa kritis dimana pertumbuhan dan perkembangannya terjadi sangat pesat. Sehingga dapat dikatakan bahwa masa anak usia dini merupakan tahap perkembangan yang penting untuk diperhatikan baik pertumbuhan maupun perkembangannya.

Perkembangan anak usia dini memiliki ruang lingkup atau aspek perkembangan yang sesuai tingkat usia anak meliputi aspek nilai agama dan moral, fisik-motorik, kognitif, bahasa, sosial-emosional, dan seni (Permendikbud RI Nomor 137 Tahun 2014 Tentang Standar Pendidikan Anak Usia Dini. Pasal 10 Butir 1, 2014). Keenam aspek perkembangan anak tersebut memiliki rentang usia tertentu dan harus berkembang secara optimal pada tingkatan usianya, artinya pada satu aspek perkembangan namun beda usia memiliki milestoon perkembangan yang berbeda pula. Ini perlu diperhatikan agar anak dapat melangkah ke tugas perkembangan selanjutnya tanpa kekurangan satu apapun.

Perhatian khusus terhadap pertumbuhan dan perkembangan anak usia 0-6 tahun dikarenakan pada masa tersebut termasuk usia golden age dimana pertumbuhan dan perkembangan anak sangat pesat dibandingkan usia-usia setelahnya. Clark, Gardner, dan Bloom menyebutkan bahawa di usia awal sel otak anak memiliki kisaran antara 100-200 miliar sel otak dan pada usia lima tahun pertama selalu diwarnai dengan keberhasilan dengan perkembangan intelektual atau kecerdasan yang mencapai 50\% (Achyar Kertamuda, 2015). Berdasar dari pendapat tersebut semakin memperkuat bahwasanya perlu adanya pemberian ransangan yang berguna untuk pengalaman anak usia dini.

Perihal memberikan pengalaman yang menyenangkan untuk anak usia dini dilakukan agar tidak terjadi beberapa gangguan psikologis pada anak. Freud menjelaskan hal ini timbul karena adanya pengalaman yang tidak menyenangkan (traumatis) seperti kekurangan kasih sayang, perpisahan dengan ibu, kekerasan, dan kegagalan dalam memenuhi kebutuhan pada masa prasekolah akan menimbulkan kecemasan yang dapat menghambat perkembangan mental atau gangguan perilaku serius, seperti mental retardation, psikosis, learning disabilities, problem bicara dan bahasa, neorosis, deliquency, dan perilaku antisosial (Riana Mashar, 2011). Gangguan-gangguan tersebut tentunya memberikan pengaruh yang buruk kepada anak, sehingga dibutuhkanlah bentuk stimulasi atau pemberian ransangan.

Pemberian ransangan menjadi sangat diperlukan untuk pertumbuhan dan perkembangan anak agar optimal. Tumbuh kembang anak saling berhubungan membentuk satu kesatuan yang tidak dapat dipisahkan. Tahap pertumbuhan dan perkembangan anak mendapat perhatian lebih mengingat proses integrasi, pembentukan kepribadian, dan kemampuan anak dimulai sejak dini. Kualitas anak juga dapat dilihat dari bagaimana proses pertumbuhan dan perkembangannya. Terhambatnya pertumbuhan dan perkembangan anak di suatu periode akan mempengaruhi perkembangan berikutnya. Keberhasilan anak usia dini dalam setiap tugas perkembangan merupakan investasi besar untuk keberhasilan anak dimasa akan datang. Hal ini menunjukkan betapa pentingnya pemberian stimulasi yang tepat diberikan kepada anak usia dini. Pemberian stimulasi juga tidak terlepas dari lingkungan anak, disini peran orang tua sangat mempengaruhi terutama keberhasilan anak dalam menyelesaikan setiap tahapan perkembangannya.

Keberhasilan anak di setiap tahap perkembangan tidak terlepas dari peran orang tua. Tidak dipungkiri bahwa keberadaan orang tua adalah lingkungan pertama bagi anak. Faktor penting orang tua ini sangat mempengaruhi usia awal anak yang selanjutnya akan berinteraksi dengan lingkungan sekitar. Dalam teori ekologi yang dikemukakan oleh 
Bronfenbrener dimana pada lapisan mikrosistem perkembangan tingkah laku anak salah satunya dipengaruhi oleh aktivitas pengasuhan di keluarga (Hurlock, 2013). Hal ini memberikan gambaran bahwa pengasuhan yang diberikan keluarga dalam berbagai aktivitas merupakan sebuah keharusan.

Bentuk aktivitas yang diberikan kepada anak dapat berupa pemberian ransangan atau stimulasi. Stimulasi merupakan pemberian ransangan kepada anak yang datang dari lingkungan luar individu anak. Stimulasi perkembangan merupakan hal yang sangat penting dalam proses tumbuh kembang anak agar optimal. Selain itu merupakan cikal bakal proses pembelajaran anak yang berupa mendidik dan melatih. Anak yang mendapat stimulasi terarah dan teratur akan lebih cepat berkembang dibandingkan dengan anak yang kurang mendapatkan stimulasi (Hashim et al., 2017). Perbedaan ini telah menunjukan bahwasanya stimulasi yang digunakan untuk perkembangan anak mampu memberikan hasil yang maksimal pada aspeknya.

Pemberian stimulasi dilakukan secara bertahap dan sesuai dengan tingkat perkembangan anak. Stimulasi dapat diberikan kepada anak, berupa pemberian makanan yang bergizi, latihan gerak, bicara, berfikir, kemandirian, dan sosialisasi. Jalal mengatakan bahwa stimulasi dalam tiga kategori yaitu gizi, kesehatan ataupun psikososial (Riana Mashar, 2011). Sehingga bentuk stimulasi yang diberikan kepada anak dapat bervariasi sesuai dengan kecakapan dari orangtua.

Pemberian stimulasi oleh orang tua berkaitan erat dengan pola asuh. Pola asuh orang tua dapat diartikan sebagai suatu cara atau metode pengasuhan yang digunakan para orang tua untuk mendidik anak-anaknya menjadi pribadi yang dewasa secara sosial (Hurlock, 2013). Pola asuh juga merupakan suatu keterampilan yang bervariasi. Cara atau metode ini tentu harus mampu dipahami oleh orang tua sehingga tercapai tujuan perkembangan secara optimal.

Pemberian asuhan berupa stimulasi kepada anak diawal-awal usia didominasi oleh peran seorang ibu. Ibu dituntut untuk aktif dan kreatif bagaimana menciptakan stimulus yang mampu memberikan dampak yang optimal untuk tumbuh dan kembang anak. Banyak cara yang dapat dilakukan oleh ibu yang memang memiliki kedekatan yang lebih kepada anak. Sebuah penelitian adanya hubungan yang signifikan antara pengasuhan dengan perkembangan anak dalam 1000 hari diawal kehidupan (Prasetyawati et al., 2019). Hal ini menjadi perhatian khusus untuk ibu, agar tidak menjadi masalah pada perkembangan anak. Sebuah studi yang mengkaji hubungan pengasuhan yang keras terhadap perkembangan kognitif dan sosial emosional anak hasilnya adalah pengasuhan yang keras mempengaruhi perkembangan kognitif dan sosial emosional anak bahkan membuat anak memiliki keterampilan verbal yang rendah (Berthelon et al., 2020).

Selain dari penelitian dari luar negeri, penelitian yang serupa dilakukan di Indonesia terjadi keterlambatan perkembangan umum belum diketahui dengan pasti, namun diperkirakan sekitar 1-3\% anak di bawah usia 5 tahun mengalami keterlambatan perkembangan umum (IDAI, 2013). Masalah lainnya dari hasil penelitian disimpulkan bahwa sebagian besar tingkat pengetahuan ibu tentang perkembangan motorik pada anak usia prasekolah (4-6 tahun) pada tingkat pengetahuan kurang. Sehingga peneliti bekerja sama dengan kader kesehatan, guru dan ibu khususnya mengenai perkembangan motorik pada anak usia prasekolah 4-6 tahun di TK Dharma Wanita Candipari Porong Sidoarjo (Annisa \& Kholiq, 2017).

Bentuk lain dari model pengasuhan yang mempengaruhi stimulasi kepada anak yaitu kearifan lokal (local wisdom) dalam memberikan stimulus perkembangan anak. Indonesia yang memang lahir dari berbagai macam suku dan bangsa tentu memiliki budaya yang dapat diambil nilai-nilai dalam meningkatkan perkembangan anak. Sebuah penelitian menggambarkan bagaimana identitas orang Aceh yang tercermin dalam pembibitan menjadi konsep pendidikan karakter dalam masyarakat Aceh sejak anak usia dini dalam bentuk puisi yang di sebut doda idi. Bait-bait doda idi mengandung nilai-nilai kemanusiaan dan ke-Tuhanan 
biasanya dinyanyikan oleh seorang ibu ketika mencoba membuat anaknya tidur di ayunan atau di tempat tidur (Herman \& Mukhlis, 2019).

Selain itu identitas budaya yang dapat memberikan stimulasi dalam perkembangan sosial anak. Sebuah penelitian tentang bentuk keterampilan sosial anak suku Bajo di Marobo dan Bajo Indah, yang dipengaruhi oleh nilai budaya leluhur serta peran keluarga, masyarakat, pemerintah dalam meningkatkan keterampilan sosial anak. Hasilnya yaitu keterampilan sosial anak suku Bajo pada dua daerah tersebut yang terwujudkan dalam bentuk fisik dan non fisik berupa Nganjama Sibbea (bekerjasama), Guru Sibbea (belajar bersama), Kukuri Sibbea (bermain bersama), Si Jagaang (saling melindungi), Situloh/Sibantoh (tolong menolong), ringan tangan membantu soliditas, terimplementasi sepenuhnya dilakukan di lingkungan sendiri dalam pengabdian dan kepatuhan pada keluarga dan masyarakat (Machmud et al., 2020).

Lebih lanjut bahwasanya perkembangan anak usia dini perlu adanya preventif yang berikan melalui kearifan budaya lokal (local wisdom). Mengadaptasi atau memodifikasi kearifan budaya lokal juga bagian dari upaya meningkatkan perkembangan anak usia dini. Selain itu penelitian yang berbasis budaya lokal juga telah mendapat perhatian akhir-akhir ini. Tujuannya untuk mengkaji bagaimana implementasi pembelajaran anak usia dini berbasis budaya lokal yaitu budaya Jawa. Proses pelaksanaan pembelajaran berbasis budaya lokal terintegrasi dalam kegiatan pijakan, kegiatan inti dan kegiatan pengasuhan kepada anak. Unsur-unsur budaya lokal Jawa yang digunakan yaitu tata nilai dalam budaya Jawa, sistem keagamaan, permainan tradisional, makanan tradisional, tarian Jawa, bahasa Jawa, sistem mata pencaharian, lagu Jawa, alat musik tradisional dan cerita rakyat (Muzakki \& Fauziah, 2015).

Selain dari daerah-daerah tersebut Sumatera Barat yang dikenal dengan budaya Minangkabau juga memiliki banyak kearifan lokal (local wisdom). Masyarakat Minangkabau sangat menjunjung tinggi adat istiadat yang berujung pada Ketuhanan dikenal dengan istilah "adat basandi sarak, sarak basandi kitabullah". Hal ini menjadikan masyarakat yang kuat dengan nilai-nilai keagamaan. Nilai-nilai inilah yang ditanamkan kepada anak semenjak kecil.

Masyarakat Minangkabau, memiliki pola menstimulai anak yang sudah lama dikenal dan dilakukan secara turun temurun yang disebut manjujai. Manjujai adalah salah satu cara para ibu di Minangkabau dalam menyampaikan nilai-nilai kebaikan kepada anak. Manjujai adalah kegiatan mengajak anak bicara, menasehati dan merangsang anak lewat harapan yang diinginkan (Gusnawilis, 2019). Bentuk-bentuk manjujai beragam seperti pantun lagu, permainan sederhana shalawat nabi dan lain-lain. Kegiatan ini biasanya dilantunkan kepada anak saat disusui atau ditimang sebelum tidur. Aktifitas manjujai ini menjadi perlu untuk dikaji kembali apa saja manfaat yang didapat oleh anak. Sehingga dapat dijadikan alasan agar budaya Manjujai ini tetap dilestarikan dan tidak termarginalkan oleh perkembangan zaman dan teknologi.

Berdasarkan latar belakang diatas, maka dalam hal ini penulis tertarik untuk mengkaji perkembangan apa saja yang dapat dipengaruhi oleh budaya. Dalam hal ini penulis mengedepankan tradisi Minangkabau yang disebut manjujai sebagai langkah preventif terhadap perkembangan anak usia dini. Penelitian ini judul "Tradisi Kearifan Lokal Minangkabau "Manjujai" untuk Stimulasi Perkembangan Anak Usia Dini".

\section{METODOLOGI}

Dalam kajian ini, penulis melakukan penelitian kualitatif deskriptif menggunakan metode library research atau disebut juga sebagai penelitian pustaka dengan mengakaji sumber yang bersifat tertulis. Library research dalam penulisan artikel bersumber dari penggunaan buku-buku dan artikel sebagai sumber datanya (Hadi, 2004). Sumber yang digunakan berasal dari sumber sekunder. Sumber sekunder adalah sumber data yang tidak langsung memberikan data kepada pengumpul data, tetapi melihat orang lain atau dengan dokumen (Sugiyono, 2013). Sumber yang digunakan berhubungan dengan perkembangan anak usia dini dan tradisi manjujai sebagai salah satu tradisi kearifan lokal Minangkabau. 


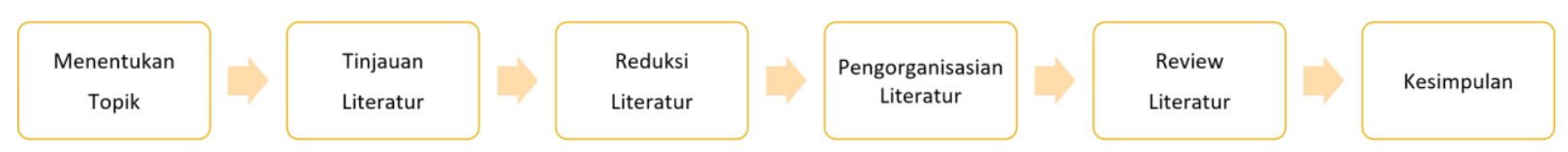

Gambar 1. Langkah-langkah Penelitian

Data penelitian dianalis menggunakan teknik analisis data kualitatif karena menggunakan kajian kepustakaan bukan berupa angka. Metode analisis data menggunakan metode desktriptif bertujuan untuk menjabarkan hasil secara mendalam, terperinci dan detail. Langkah-langkah yang dilakukan pada penelitian ini adalah menentukan topik penelitian, melakukan tinjauan berbagai sumber literatur, reduksi literatur, pengorganisasian literatur, review literatur, dan terakhir menarik kesimpulan.

\section{HASIL DAN PEMBAHASAN}

\section{Manjujai sebagai Stimulasi Perkembangan Anak Usia Dini}

Anak usia dini mengalami pertumbuhan dan perkembangan. Pertumbuhan terjadi secara kuantitatif artinya dapat diukur perubahannya. Sedangkan perkembangan terjadi secara kualitatif dimana adanya proses menuju suatu kematangan. Perkembangan diartikan sebagai pola perubahan yang dimulai semenjak pembuahan dan terus berlanjut sepanjang rentang kehidupan individu dan terjadi perubahan progresif akibat dari proses kematangan dan pengalaman belajar (Santrock, 2007; Hurlock, 2000). Sehingga baik pertumbuhan maupun perkembangan terjadi secara terus menerus dan saling berkesinambungan diantara keduanya.

Terdapat dua faktor utama yang berpengaruh terhadap tumbuh kembang anak yaitu seperti pada gambar berikut (Mansur, 2019):

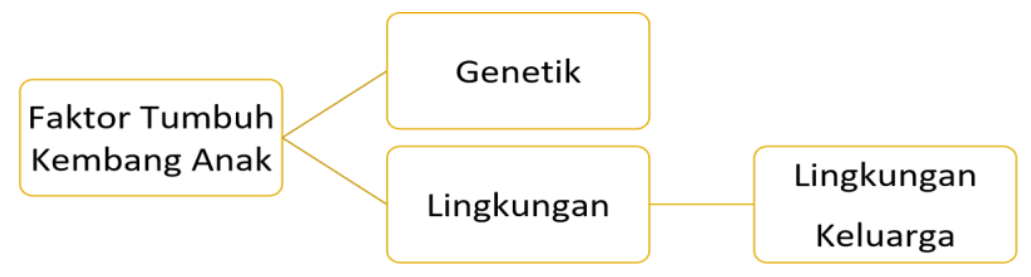

Gambar 2. Faktor yang berpengaruh terhadap tumbuh kembang anak

\section{Genetik}

Pada saat pembuahan sel telur oleh sel sperma, setiap manusia menerima jumlah kromosom yang sama sebanyak 23 pasang dari orangtuanya. Karakteristik yang diwarisi membawa informasi genetik yang menentukan diferensiasi, pertumbuhan, dan fungsi seluler orang tersebut. Sebagai hasilnya dapat dilihat seperti karakteristik fisik seperti tinggi, ukuran tulang, dan warna mata dan rambut diwariskan dari keturunan keluarganya.

\section{Lingkungan}

Faktor lingkungan yang sering disebut milieu merupakan tempat anak tersebut hidup, dan berfungsi sebagai penyedia kebutuhan dasar anak. Lingkungan dapat dikelompokkan ke dalam 4 macam lingkungan, yaitu : lingkungan keluarga, lingkungan perlindungan kesehatan anak, lingkungan masyarakat, dan lingkungan stimulasi atau pendidikan.

Faktor lingkungan termasuk di dalamnya kebiasaan yang ada di masyarakat tentu mendapat perhatian khusus. Layaknya Indonesia yang terbentang dari sabang sampai merauke memiliki banyak ragam budaya yang berbeda, bukan hanya berbeda dalam budaya, bahasa maka juga kearifan lokal (local wisdom) ini memiliki ciri khas tersendiri. Kearifan lokal ini juga yang membedakan antara daerah satu dengan yang lainnya salah satunya dalam hal pengasuhan anak. Seperti pengaruh budaya Lampung yang menganut prinsip patrilineal 
terhadap perbedaan perlakuan kepada anak laki-laki dan perempuan hal ini menyebabkan egosentris anak laki-laki lebih tinggi dibanding anak perempuan (Fitria, 2016).

Contoh lain kearifan lokal dalam pola mendidik anak juga terdapat dalam cerita Hikayat Inderaputra dari daerah melayu. Ditemukan bahwa bentuk pengasuhan adalah bersukacita atas kelahiran anak, memberi nama yang baik pada anak, memberi perlindungan pada anak, bersyukur atas kelahiran anak, mengenalkan agama pada anak, dan mendoakan anak, selain itu menjaga kebersihan anak dan membahagiakan anak (Purnama \& Hidayati, 2020). Seperti halnya pengasuhan yang berada di masing-masing daerah sebagai bentuk kearifan lokal, daerah Minangkabau, Sumatera Barat juga dikenal dengan tradisinya yaitu manjujai.

Secara harfiah manjujai diartikan sebagai nina bobo yaitu kegiatan mengajak anak bicara, menasehati dan merangsang anak lewat harapan kita (Gusnawilis, 2019). Lebih lanjut manjujai merupakan media pembelajaran terhadap bayi dalam pendidikan internalisasi nilai dimana sang nenek/ibu mengajak berkomunikasi, meskipun anak belum bisa apa-apa. Pada saat tersebutlah biasanya Manjujai diberikan kepada anak, di mana pada usia awal tersebut anak masih bergantung pada ibunya. Gerakan mulut dan tangan dari ibu/nenek menjadi perhatian bayi sejak lahir hingga usia 2 tahun dan meransangnya untuk mengikuti apa yang dilakukan oleh ibu/nenek (Ernatip \& Devi, 2014; Helmizar, 2016)

Selain itu manjujai merupakan kegiatan perangsangan (penglihatan, bicara, pendengaran, perabaan) dengan cara bercakap-cakap, bernyanyi serta bermain dengan anak (Helmizar et al., 2019). Hal ini dapat membantu anak mencapai tingkat pertumbuhan dan perkembangan secara optimal. Sehingga Manjujai menjadi kewajiban semua orang yang berada disekitar anak untuk memberi stimulasi yang menyenangkan agar anak merasa nyaman dan dicintai oleh lingkungannya. Selain membantu menidurkan anak dengan nyenyak aktivitas manjujai juga dapat mendekatkan dan mempererat hubungan anak dengan ibunya serta memberikan rasa nyaman (Satria, 2019).

Oleh karenanya aktivitas manjujai sebagai salah satu budaya minangkabau dapat digunakan sebagai salah satu stimulasi yang diberikan kepada anak usia dini. Stimulasi diberikan untuk meningkatkan aspek perkembangan anak dan membangun kelekatan antara anak dengan ibunya.

\section{Perilaku Pengasuhan Manjujai pada Anak Usia Dini}

Pada teori ekologi manusia mempelajari interelasi antar manusia dan lingkungannya. Berns menyebutkan ada empat dasar dalam konsep tersebut yaitu sistem mikro, meso, exo dan makro (Suryana, 2016). Sistem mikro adalah keluarga dan hubungan antara keluarga. Keluarga merupakan tempat pertama dan yang utama dimana anak-anak belajar, mempelajari sifat-keyakinan, sifat-sifat mulia, komunikasi dan interaksi sosial, serta keterampilan hidup (Hasbi Indra, 2017). Keluarga disini merupakan struktur terkecil dalam lingkungan yang terdiri dari orang tua dan anak. Dalam perkembangannya anak mempunyai kebutuhan yang harus dipenuhi selain kebutuhan primer seperti kasih sayang, rasa aman, perhatian daln lainnya. Salah satunya dapat diberikan oleh orang tua melalui pengasuhan yang positif kepada anak.

Brooks, Garbarino \& Benn menyebutkan bahwa pengasuhan atau parenting merupakan sebuah proses menjadi orangtua yang berperan untuk mengasuh, melindungi, dan membimbing anak dengan hangat, sensitif, penuh penerimaan, bersifat resiprokal, ada pengertian, dan respon yang tepat pada kebutuhan anak dari bayi hingga ke tahap dewasa (Andayani \& Koentjoro, 2004; Brooks, 1986). Selain itu pengasuhan diartikan sebagai penerapan serangkaian keputusan tentang sosialisasi anak-anak, hal yang akan dilakukan orangtua untuk membentuk anak menjadi bertanggungjawab, menjadi bagian dari anggota masyarakat, dan juga dengan apa yang akan dilakukan orangtua ketika anak mengalami permasalahan emosional seperti menangis, bersikap agresif, berbohong, atau mengalami 
hambatan di sekolah (Berns, 2012). Berdasarkan hal tersebut pada dasar pengasuhan kepada anak banyak diambil alih oleh peran seorang ibu.

Pengasuhan yang dilakukan oleh ibu merupakan pola asuh psikososial berupa pemberian stimulasi akan memengaruhi perkembangan anak. Stimulasi psikososial adalah serangkaian kegiatan perangsangan (penglihatan, bicara, pendengaran, perabaan) yang datang dari lingkungan anak yang bertujuan untuk membantu anak mencapai tingkat perkembangan yang optimal. Bradley dkk. menyebutkan bahwa pola asuh psikososial meliputi reaksi emosi, dorongan positif, suasana yang nyaman, dan kasih sayang yang ditunjukkan orang tua, serta sarana tumbuh kembang dan belajar. Pola asuh dengan memberikan stimulus psikososial kepada anak akan mampu meningkatkan perkembangan motorik, kognitif, sosial emosi dan moral/karakter pada anak (Hastuti, 2009; Helmizar, Jalal, et al., 2017).

Pakar psikologi perkembangan yaitu Erikson memfokuskan pada perkembangan psikososial yang terdiri dari delapan tahap. Pada usia dini, teori Erikson memiliki tiga tahapan yaitu kepercayaan vs kecurigaan, otonomi vs perasaan malu dan ragu-ragu, dan inisiatif vs kesalahan (Jamaris, 2006). Bermodalkan rasa percaya diri dan sejalan dengan perkembangan fisik, kognitif, dan bahasa anak mulai mengeksplorasi lingkungannya sehingga merasakan kebebasan. Seiring dengan itu berkembang pula krisis tahap kedua dalam diri anak. Krisis ini ditandai dengan mulai berkembangnya rasa malu dalam diri anak. Rasa malu ini merupakan awal dari kepekaan anak terhadap sesuatu yang salah dan yang benar. Anak usia prasekolah juga belajar dari cara orang lain merespon emosi mereka. Keterampilan sosial-emosional terkait erat dengan keluarga anak, latar belakang budaya, dan pengalaman awal, etnisitas, dan status sosial ekonomi dimana anak-anak belajar dengan berinteraksi dan membentuk hubungan dengan anggota keluarga, sekolah, dan komunitas mereka (Mansur, 2019; Santrock, 2007).

Hal ini menjadi penguat bahwasanya stimulasi psikosial sangat dibutuhkan oleh anak lebih khusus ketika anak masih dalam usia yang sangat muda. Chamidah menyebutkan bahwa anak yang mendapatkan stimulasi yang terarah akan lebih cepat berkembang dibandingkan anak yang kurang bahkan tidak mendapatkan stimulasi. Lebih lanjut menjelaskan bentuk stimulasi psikososial yang diberikan kepada anak yaitu dengan aktivitas manjujai (Helmizar et al., 2019).

Dengan demikian dapat dijelaskan bahwa pengasuhan yang diberikan oleh ibu kepada anak melibatkan kasih sayang, kenyamanan, dapat mendorong tumbuh dan berkembanga sesuai tahapannya. Hal inilah yang disebut dengan pola asuh spikososial. Salah satu bentuk stimulasi dalam pola asuh spikososial yang telah diterapkan di masyarakat minangkabau yaitu dengan aktivitas manjujai.

\section{Tradisi Manjujai Terhadap Perkembangan Anak}

Pada poin pembahasan ini menjelaskan mengenai tradisi manjujai dapat digunakan sebagai stimulasi perkembangan anak usia dini yang bersumber dari beberapa hasil penelitian. Hal ini didukung dari berbagai sumber jurnal penelitian yang menggambarkan mengenai stimulasi manjujai memiliki pengaruh terhadap perkembangan anak usia dini.

\section{Perkembangan Bahasa}

Bahasa merupakan ungkapan dalam mengekspresikan pikiran dan kreativitas. Kosakata pada anak usia 3 tahun terdiri dari sekitar 900 kata dan pada usia 5 tahun biasanya memiliki kosakata 2.100 kata dengan perolehan sebanyak 10 hingga 20 kata baru per hari (Taylor et al., 2011). Bentuk komunikasi yang diberikan kepada anak merupakan komunikasi konkret dan sederhana sehingga mudah dipahami oleh anak usia dini.

Perkembangan bahasa anak dipengaruhi oleh maturationist (kedewasaan) dan environmental (lingkungan). Pengaruh kedewasaan pada pemerolehan bahasa anak merupakan pembawaan lahir pada setiap anak tanpa memandang Negara atau budaya. 
Munculnya bahasa pada anak ketika sudah waktunya dan pada waktu "resonansi" perkembangan itu terjadi atau dapat dikatakan terjadi secara alami. Sedangkan pengaruh lingkungan pada pemerolehan bahasa anak berdasar pada jadwal biologis, sedangkan isi sintaksis bahasa, tata bahasa, dan kosakata diperoleh dari lingkungan, yang mencakup orangtua dan orang lain sebagai model pengguna bahasa. Proses biologis pada anak dapat dikatakan sama, namun isi bahasa mereka akan berbeda tergantung pada faktor lingkungan seperti pembicaraan antara anak dengan orang dewasa, dan juga antara anak dengan anak. Selian itu tergantung pada interaksi dengan model pengguna bahasa lain (Masriqon, 2015).

Dimana tahap perkembangan komunikasi anak menurut Santoso (Wardhana, 2013) dapat dilihat dalam Tabel 1:

Tabel 1. Tahapan Perkembangan Bahasa Bayi

\begin{tabular}{ccl}
\hline No & Usia & \multicolumn{1}{c}{ Tahapan } \\
\hline 1 & $0-3$ minggu & $\begin{array}{l}\text { Reflexive vocalization ditandai dengan suara tangisan } \\
\text { yang masih berupa refleks. }\end{array}$ \\
\hline 2 & $>3$ minggu & $\begin{array}{l}\text { Babbling ditandai dengan menangis ketika bayi merasa } \\
\text { lapar atau tidak nyaman. }\end{array}$ \\
\hline 3 & $2-6$ bulan & $\begin{array}{l}\text { Lulling ditandai dapat mengucapkan suku kata } \\
\text { berulang seperti ba-ba, ma-ma. }\end{array}$ \\
\hline 4 & 10 bulan & $\begin{array}{l}\text { Echolalia ditandai dengan meniru suara-suara yang di } \\
\text { dengar dari lingkungannya, serta ia juga akan } \\
\text { menggunakan ekspresi wajah atau isyarat tangan ketika } \\
\text { ingin meminta sesuatu. }\end{array}$ \\
\hline 5 & 18 bulan & $\begin{array}{l}\text { True speech ditandai dengan bayi mulai dapat berbicara } \\
\text { dengan benar, namun pengucapannya belum sempurna } \\
\text { seperti orang dewasa. }\end{array}$ \\
\hline
\end{tabular}

Irwan (2016) mengatakan dalam hasil telaahnya bahwa tradisi Minangkabau dapat memberikan dampak terhadap pemerolehan bahasa anak. Para orang tua dari dahulu kala sering membuat anaknya tertawa dengan berbagai ungkapan yang lucu baik melalui bahasa atau melalui gerak verbal yang kemudian disebut dengan tradisi bajujai atau manjujai anak. Hal tersebut juga sejalan dengan adanya pemberian stimulasi psikososial memiliki pengaruh terhadap peningkatan perkembangan bahasa, motorik dan kognitif anak melalui gabungan suplementasi makanan dan stimulasi psikososial berupa aktivitas manjujai (Helmizar, Resmiati, et al., 2017).

Adapun cara menyampaikan stimulasi manjujai dengan berbagai cara manjujai yaitu melalui nyanyian atau senandung sehingga dapat membentuk nada. Nada yang digunakan oleh itu berbeda-beda tergantung bagaimana cara ibu bernyanyi. Syafputra menjelaskan bahwa nada yang digunakan oleh ibu juga muncul dari pertunjukan kesenian tradisional Minangkabau seperti "saluang dendang" yang kemudian dimodifikasi membentuk lirik tak bermakna namun merdu "na-na-na, du-du-du, iyo" dan lainnya (Albert Efendi Pohan, S. Pd., 2020).

Uraian di atas dapat mengungkapkan bahawa manjujai memiliki pengaruh terhadap perkembangan bahasa anak usia dini lebih khusus anak berusia 0-2 tahun. Intervensi yang diberikan dengan tujuan untuk berkomunikasi dengan anak, dan meningkatkan pemerolehan bahasa anak. Selain itu juga memberikan efek menggembirakan ketika mengajak anak berbicara dengan manjujai.

\section{Perkembangan Sosial-Emosional}

Proses sosial terdiri dari tiga proses yaitu belajar bertingkah laku dengan cara yang diterima masyarakat, belajar memainkan peran sosial serta mengembangkan sikap sosial dan aktivitas sosial dimasyarakat. Fungsi emosi pada anak yaitu sebagai bentuk komunikasi 
dengan lingkungan, sebagai bentuk kepribadian dan penilaian anak terhadap dirinya, sebagai bentuk tingkah laku yang dapat diterima lingkungannya, sebagai bentuk pembiasaan dan sebagai upaya pengembangan diri (Suryana, 2016). Sehingga perkembangan sosial emosional anak sangat penting untuk diperhatikan dan distimulasi.

Anak usia dini memiliki emosi yang kuat dan belum konsisten dimana anak memiliki emosi yang berubah dalam waktu yang dekat. Kyle menyebutkan bahwa anak sudah mampu memahami peran sesuai dengan identitasnya dan mengetahui bahwa memiliki keluarga, komunitas, atau budaya tertentu (Mansur, 2019). Lebih lanjut Mansur menambahkan bahwa anak mampu membantu orang lain dan terlibat dalam rutinitas. Dalam hal ini orang tua dapat memberikan dukungan dan membantu anak dengan mengembangkan keterampilan sosial dan emosional yang akan dibutuhkan oleh anak. Orang tua juga dapat mengembangkan komunikasi anak dengan kegiatan interaksi untuk mengekspresikan perasaan dan idenya. Komunikasi interaktif tidak hanya menumbuhkan perkembangan emosional dan moral tetapi juga harga diri dan perkembangan kognitif untuk anak.

Slavin mengungkapkan bahwa terdapat tiga kondisi utama yang mempengaruhi perkembangan sosial emosional anak yaitu kondisi fisik, kondisi psikologis dan kondisi lingkungan (Suryana, 2016). Hal inilah yang coba disampaikan bahwa para orang tua dari dahulu kala sering membuat anaknya tertawa dengan berbagai ungkapan yang lucu baik melalui bahasa atau melalui gerak verbal yang kemudian disebut dengan tradisi bajujai atau manjujai anak. Respon yang diberikan anak baru bisa sekedar tertawa. Tertawa anak inilah merupakan jawaban dari lelucon yang disampaikan oleh orangtuanya. Hal ini memperkuat bahwa respon yang dapat diberikan anak saat proses manjujai berupa tertawa mengartikan tujuannya untuk anak usia dini yang belum mampu memberikan respon terhadap kegiatan lainnya (Irwan, 2016).

Berdasarkan hal tersebut manjujai juga dapat menstimulasi perkembangan emosional sosial emosional anak dengan adanya interaksi dan umpan balik oleh ibu dan anak. Manjujai yang dilakukan oleh ibu kepada anaknya membuat hubungan keduanya menjadi lebih erat sehingga menimbulkan rasa aman dan menyenangkan untuk anak.

\section{Perkembangan Moral dan Spiritual}

Kohlberg mengidentifikasi pada tahap anak usia dini (antara 2 dan 7 tahun) sebagai tahap prakonvensional, yang ditandai dengan orientasi hukuman dan kepatuhan. Kyle menambahkan Standar moral anak adalah standar orang tua mereka atau orang dewasa lain yang memengaruhi mereka (anak), belum tentu milik mereka sendiri sehingga mereka tunduk pada kekuasaan (orang dewasa) sehingga tidak selalu mudah untuk mengetahui pada usia berapa anak yang tepat untuk dibimbing secara moral atau bahkan bagaimana cara memulainya (Mansur, 2019)

Aktivitas manjujai yang sering dilakukan di lingkungan masyarakat Minangkabau dilakukan setiap hari dengan materi yang berbeda seperti lagu klasik minang, cerita rakyat, atau berupa kata-kata saja. Materi yang diberikan mengandung nilai-nilai yang biasa diterapkan di dalam masyarakat Minangkabau seperti:

Eeiii..

Dari ketek kini lah gadang

Mandeh kasuah jo kasiah sayang

Nyamuak saikua mandeh halaukan nak eei

Baitu sayang ka anak surang

Eeii...

Berdasarkan syair manjujai di atas menceritakan kasih sayang orang tua yang begitu besar kepada anaknya. Selain syair di atas banyak lagi syair yang digunakan untuk manjujai anak. Nilai-nilai yang terkandung di dalamnya digunakan untuk memperkuat perkembangan nilai dan moral anak dimana anak mampu untuk membedakan mana perilaku yang baik dan buruk. Hal ini juga yang membuat manjujai dapat digunakan dalam perkembangan nilai moral anak usia dini. Lebih lanjut menjelaskan bentuk-bentuk manjujai beragam seperti 
pantun lagu, permainan sederhana shalawat nabi dan lain-lain. Kegiatan ini biasanya dilantunkan kepada anak saat disusui atau ditimang sebelum tidur (Albert Efendi Pohan, S. Pd., 2020).

\section{Perkembangan Fisik-Motorik}

Perkembangan fisik individu meliputi empat aspek yaitu sistem saraf, otor-otot, kelenjar endrokrin, dan srtuktur fisik/ tubuh (Hurlock, 2006). Kemampuan motorik dipengaruhi oleh energi yang dimiliki oleh anak usia dini. Childdevelopment memberikann gambaran mengenai kemampuan motorik anak. Motorik terbagi atas dua yaitu motorik kasar dan motorik halus. Keterampilan motorik kasar (fisik) adalah keterampilan yang membutuhkan gerakan seluruh tubuh dan yang melibatkan otot-otot besar untuk melakukan fungsi sehari-hari. Kegiatan motorik kasar seperti berdiri dan berjalan, berlari dan melompat, dan duduk tegak di meja, melakukan koordinasi mata-tangan seperti keterampilan bola (melempar, menangkap, menendang) serta mengendarai sepeda atau skuter dan berenang (Mansur, 2019).

Lebih lanjut State Government of Victoria menggambarkan keterampilan motorik halus anak diperlukan untuk banyak aspek perawatan diri, misalnya: mengenakan sepatu, makan sendiri, membersihkan gigi sendiri. Pengembangan motorik halus sangat penting dalam mengembangkan kemampuan membuat tanda dan menulis secara efektif sehingga pesan dapat dikomunikasikan (Mansur, 2019)

Jalal juga menjelaskan bahwa stimulasi psikososial dapat berupa pemberian kehangatan dan cinta, pengalaman langsung dengan indera pengalihatan, pendengaran, perasa, peraba, penciuman), interaksi melalui sentuhan, pelukan, senyuman, nyanyian, mendengarkan dengan penuh perhatian, menanggapi ocehan anak, mengajak bercakap-cakap dengan suara lembut dan memberi rasa aman (Riana Mashar, 2011).

Stimulasi manjujai untuk peningkatan perkembangan motorik anak dikemukakan oleh Delima dkk. yang melakukan penelitian dengan tujuan untuk melihat pengaruh pendidikan kesehatan manjujai dapat meningkatkan pengetahuan dan keterampilan Ibu. Upaya stimulasi perkembangan motorik anak untuk usia 12-24 bulan di wilayah kerja puskesmas Belimbing. Hasil penelitian rata-rata tingkat pengetahuan ibu sebelum diberi perlakuan 18,42 dan setelah diberi perlakuan meningkat menjadi 22,78. Distribusi perkembangan Motorik Halus pretest $73,3 \%$ pada kategori terlambat dan post-tes menurun menjadi $16,7 \%$. Perkembangan Motorik kasar anak pre-test sebanyak $66,7 \%$ dan post-test menjadi $13,3 \%$. Sehingga ada pengaruh pemberian pendidikan kesehatan menggunakan modul Manjujai anak terhadap tingkat pengetahuan ibu, perkembangan motorik halus anak perkembangan motorik kasar anak. Dalam rangka menstimulasi perkembangan motorik halus dan motorik kasar anak. Modul manjujai dapat dijadikan sebagai salah satu alternatif yang dapat digunakan meningkatkan perkembangan anak, khususnya perkembangan motorik anak usia dini (Delima et al., 2019).

Berdasarkan hal tersebut menjelaskan bahwa manujai tidak hanya untuk meningkatkan perkembangan bahasa, sosial-emosional, moral spiritual tetapi juga dapat digunakan untuk meningkatkan perkembangan fisik-motorik anak. Manjujai yang dilakukan kepada anak sangat berpengaruh terhadap bentuk stimulasi yang diberikan orang tua sehingga orang tua juga paham dengan manjujai yang diberikan kepada anak.

\section{Perkembangan Kognitif}

Menurut teori Piaget (Hurlock, 2013) perkembangan kognitif anak dikenal dengan empat tahap yaitu tahap sensori motor (lahir - 2 tahun), tahap pra-operasional (usia 2-7 tahun), tahap operasi kongkret (usia 7-11 tahun) dan tahap operasional formal (usia 11-15 tahun). Anak usia dini berada di dua tahap yaitu sensori motor dan pra-operasional. Pemikiran praoperasi mendominasi selama tahap ini dan didasarkan pada pemahaman dunia yang mementingkan diri sendiri. Sedangkan Slavin (Suryana, 2016) menerangkan Perkembangan kognitif anak usia dini pada hakikatnya merupakan proses asimilasi, akomodasi, dan 
ekuilibrum. Pada fase prakonseptual pra-operasi berpikir, anak tetap egosentris dan mampu mendekati masalah hanya dari satu sudut pandang (Mansur, 2019)

Selain Piaget, Vygotsky juga memiliki pandangan terkait perkembangan kognitif anak usia dini. Vygotsky memandang bahwa sistem sosial berupa orang tua, guru dan teman sangat penting dalam perkembangan kognitif anak. Dalam hal ini anak usia dini berada dalam konteks zone of proximal development (ZPD) yang diartikan sebagai suatu daerah potensial anak untuk diajarkan atau kemampuan anak ditingkatkan melalui bantuan atau scaffolding (Hurlock, 2013). Berdasarkan pendapat kedua tokoh tersebut penting untuk anak usia dini diberikan stimulasi agar perkembangan kognitif anak sesuai dengan tahap usia dan kemampuannya.

Manjujai dapat memberikan stimulasi psikososial yang bermanfaat bagi tumbuh kembang anak. Pemberian stimulasi psikososial ini berpengaruh terhadap peningkatan perkembangan bahasa, motorik dan kognitif anak melalui gabungan suplementasi makanan dan stimulasi psikososial berupa aktivitas manjujai (Helmizar, Resmiati, et al., 2017). Intensitas dan kualitas stimulasi yang diberikan oleh ibu atau pengasuh dapat juga memperkuat ikatan anak dengan ibu atau pengasuh sehingga masalah yang berhubungan dengan kesulitan makan yang mengganggu pertumbuhan dan perkembangan anak akan dapat diatasi. Lebih lanjut Helmizar dkk. menegaskan bahwa orang tua yang memiliki anak dengan pola asuh stimulasi psikososial yang kurang akan berisiko 2,99 kali menderita stunting dibandingkan responden dengan pola asuh stimulasi psikososial yang baik. Artinya manjujai selain sebagai bentuk stimulasi dapat juga sebagai intervensi.

Pemaparan tersebut menggambarkan bahwa manjujai bukan hanya dapat digunakan untuk stimulasi perkembangan bahasa dan motorik namun juga dapat digunakan sebagai stimulasi perkembangan kognitif anak. Sehingga manjujai menjadi salah satu bentuk stimulasi yang harus dikembangkan dan dilestarikan.

Penjabaran tersebut di atas membuktikan bahwa manjujai dapat mengingkatkan perkembangan bahasa, sosial-emosioanal, moral-spiritual, kognitif dan motorik baik motorik halus maupun motorik kasar anak usia dini. Hal ini membuat manjujai yang menjadi tradisi rakyat Minangkabau mendapat perhatian kembali. Sebahagian daerah sudah menjadikan tradisi ini sebagai bahan pelatihan yang diberikan kepada stakeholder terkait seperti orang tua, pengasuh, dan kader-kader posyandu yang ada. Program ini memiliki harapan kepada kader posyandu yang ada baik di kampung KB dan bundo kanduang, dengan adanya program Ketahanan Keluarga BKB berupa pemberian stimulan manjujai dapat melanjutkan program di tingkat kabupaten dan kota di wilayah Sumatera Barat (Yulia, 2017). Program ini dalam rangka meningkatkan wawasan dan pengetahuan keluarga dan anggota keluarga yang mempunyai anak Balita tentang bagaimana mengasuh dan mendidik anak Balita agar dapat tumbuh dan berkembang secara baik dan benar tentu tidak melupakan warisan budaya.

Berdasarkan penjelasan yang telah disebutkan bahwa aktivitas manjujai dapat dijadikan sebagai intervensi untuk perkembangan anak usia dini. Stimulasi ini dapat meningkatkan perkembangan pemerolehan nilai-nilai dan moral anak, perkembangan bahasa, motorik, sosial-emosional, dan kognitif anak usia dini. Selain itu bentuk stimulasi psikososial ini dapat meningkatkan hubungan atau kelekatan antara ibu dan anak, memberikan rasa nyaman, aman, dan bahagia anak tentunya mempengaruhi pertumbuhan dan perkembangan anak secara optimal.

\section{SIMPULAN}

Eksistensi kearifan lokal atau local wisdom selama ini mungkin masih terabaikan oleh kita. Bila melihat fenomena yang ada di masyarakat yang sudah dilaksanakan dan ditradisikan oleh nenek moyang kita adalah sebuah warisan budaya yang tidak terlepas dari kandungan nilai-nilai yang tidak bisa diabaikan kebenarannya. Nilai-nilai yang diwariskan dapat digunakan pada masa sekarang baik diadopsi atau mengalami adaptasi sesuai dengan perkembangan zaman. Berdasarkan uraian diatas bahwasanya salah satunya tradisi adat 
Minangkabau yaitu Manjujai berpengaruh terhadap perkembangan kognitif, bahasa, dan motorik anak usia dini baik morik kasar maupun motorik halus.

\section{UCAPAN TERIMA KASIH}

Ucapan terima kasih disampaikan kepada Ibu Puji Yanti Fauziah selaku dosen mata kuliah Pendidikan dan Pengasuhan Anak Usia Dini, Program Pascasarjana Universitas Negeri Yogyakarta, yang telah membimbing serta memberikan rekomendasi untuk terbitnya artikel ini kemudian kepada Lembaga Pengelola Dana Pendidikan (LPDP) yang telah memberikan dukungan materil.

\section{DAFTAR PUSTAKA}

Achyar Kertamuda, M. (2015). Golden Age (Strategi Sukses Membentuk Karakter Emas pada Anak Usia Dini). Alek Media Komputindo.

Albert Efendi Pohan, S. Pd., M. P. (2020). Literacy Goes To School: GERAKAN LITERASI NASIONAL. Qiara Media.

Andayani, B., \& Koentjoro. (2004). Psikologi Keluarga: Peran Ayah Menuju Coparenting (Pertama). Citra Media.

Annisa, F., \& Kholiq, A. A. (2017). Studi Tingkat Pengetahuan Ibu Tentang Perkembangan Motorik Pada Anak Usia PRA Sekolah (4-6 Tahun) Di Tk Dharma Wanita Candipari Porong Sidoarjo. Nurse and Health: Jurnal Keperawatan, 6(1), 5-6. https:// doi.org/10.36720/nhjk.v6i1.15

Berns, R. M. (2012). C HILD , F AMILY, Ninth Edition (9th ed.). Cengage Learning.

Berthelon, M., Contreras, D., Kruger, D., \& Palma, M. I. (2020). Harsh parenting during early childhood and child development. Economics and Human Biology, 36. https:/ / doi.org/10.1016/j.ehb.2019.100831

Brooks, J. (1986). The Process of Parenting (Book). Journal of Clinical Child Psychology, 15(4), 380-380. https://doi.org/10.1207/s15374424jccp1504_19

Delima, D., Metti, E., \& Irfan, A. (2019). Pendidikan Kesehatan "Manjujai Anak" Terhadap Pengetahuan Ibu dan Perkembangan Motorik Anak 12 - 24 Bulan. Jik- Jurnal Ilmu Kesehatan, 3(2), 123. https:/ / doi.org/10.33757/jik.v3i2.240

Ernatip, \& Devi, S. (2014). Kedudukan dan peran bundo kanduang dalam Sistem Kekerabatan Matrilineal di Minangkabau.

Fitria, N. (2016). Pola Asuh Orang Tua Dalam Mendidik Anak Usia Prasekolah Ditinjau Dari Aspek Budaya Lampung. Jurnal Fokus Konseling, 2(2), 99-115. https:/ / doi.org/32536457784

Gusnawilis. (2019). Manjujai, Budaya Minangkabau yang Ampuh Tangkal Stunting di Sumatera Barat. Suara.Com.

Hadi, S. (2004). Metodologi Research (1st ed.). Andi Offset.

Hasbi Indra. (2017). Pendidikan Keluarga Islam (1st ed.). Remaja Rosdakarya.

Hashim, T. H., Mgongo, M., Katanga, J., Uriyo, J. G., Damian, D. J., Stray-Pedersen, B., Wandel, M., \& Msuya, S. E. (2017). Predictors of appropriate breastfeeding knowledge among pregnant women in Moshi Urban, Tanzania: A cross-sectional study. International Breastfeeding Journal, 12(1), 1-8. https:/ / doi.org/10.1186/ s13006-017-0102-4

Hastuti, D. (2009). "Stimulasi Psikososial pada Anak Kelompok Bermain di Kota Bogor dan Pengaruhnya pada Perkembangan Motorik, Kognitif, Sosial Emosi dan Moral/Karakter Anak." Jurnal Ilmu Keluarga Dan Konsumen, 2(1), 41-56. https:// doi.org/10.24156/jikk.2009.2.1.41

Helmizar. (2016). Keberlanjutan Efek Suplementasi Gizi dan Stimulasi Psikososial Manjujai Sewaktu Usia Kurang 2 Tahun terhadap Tumbah Kembang Anak Usia 3-5 Tahun ( a Follow Up Study).

Helmizar, H., Jalal, F., Lipoeto, N. I., \& Achadi, E. L. (2017). Local food supplementation and psychosocial stimulation improve linear growth and cognitive development among 
Indonesian infants aged 6 to 9 months. Asia Pacific Journal of Clinical Nutrition, 26(1), 97-103. https://doi.org/10.6133/apjcn.102015.10

Helmizar, Resmiati, \& Putra, D. A. (2017). Efek Jangka Panjang Pemberian Sumplementasi Gizi dan Stimulasi Psikososial terhadap Tumbuh Kembang Anak Usia 5 Tahun di Kabupaten Tanah Datar Tahun 2017 (A Follow Up Study). In Jurnal Kesehatan Masyarakat Andalas.

Helmizar, Resmiati, \& Putra, D. A. (2019). Faktor Resiko Kejadian StuntingPada anak Usia 35 Tahun di Kabupaten Tanah Datar Tahun 2018 (A Follow Up Study). Kesehatan Masyarakat Andalas, 13(2), 10-16. http://jurnal.fkm.unand.ac.id/index.php/jkma/

Herman, R., \& Mukhlis, A. H. (2019). Identity Education As the Concept of Acehnese Character Education Through Nursery Rhymes. 978-623. https:/ / doi.org/10.24815/.v1i1.14425

Hurlock. (2013). Perkembangan Anak Jilid 1 Edisi 6. Jakarta: Erlangga.

Hurlock, E. B. (2006). Psikologi Perkembangan: Suatu Pendekatan Sepanjang Rentang Kehidupan. (Penerjemah: Istiwidayanti, Soedjarwo). (5th ed.). Erlangga.

IDAI. (2013). Mengenal Keterlambatan Umum Pada Anak.

Jamaris, M. (2006). Perkembangan dan Pengembangan Anak Usia TK. Grasindo.

Machmud, H., Alim, N., \& Ulviya, L. (2020). Keterampilan Sosial Anak Suku Bajo di Sulawesi Tenggara. Jurnal Obsesi: Jurnal Pendidikan Anak Usia Dini, 4(2), 787. https://doi.org/10.31004/obsesi.v4i2.459

Mansur, A. R. (2019). Tumbuh Kembang Anak Usia Prasekolah (1st ed.). Andalas Unoversity Press.

Masriqon. (2015). Ilmu Pendidikan Anak Usia Dini (5th ed.). Indeks.

Muzakki, M., \& Fauziah, P. Y. (2015). Implementasi pembelajaran anak usia dini berbasis budaya lokal di PAUD full day school. Jurnal Pendidikan Dan Pemberdayaan Masyarakat, 2(1), 39-54. https:// doi.org/10.21831/jppm.v2i1.4842

Papalia, D. E., Feldman, R. D., \& Olds, S. W. (2008). Human Development (Psikologi Perkembangan) (9th ed.). Kencana.

Prasetyawati, N., Tamtomo, D. G., Hanim, D., \& Salimo, H. (2019). The correlation between child spacing (heading), exclusive breastfeeding and parenting with child development at first 1000 days of life. Indian Journal of Public Health Research and Development, $10(12)$,

1890-1894.

https://doi.org/10.37506/v10/i12/2019/ijphrd/192144

Purnama, S., \& Hidayati, L. (2020). Pengasuhan Anak Usia Dini dalam Hikayat Indraputra. Jurnal Obsesi: Jurnal Pendidikan Anak Usia Dini, 4(2), 520. https://doi.org/10.31004/obsesi.v4i2.391

Undang-undang Nomor 20 Tahun 2003 tentang Sistem Pendidikan Nasional Pasal 1, Butir 14, Pub. L. No. 20 (2003).

Permendikbud RI Nomor 137 Tahun 2014 tentang Standar Pendidikan Anak Usia Dini. Pasal 10 Butir 1, Pub. L. No. 137 (2014).

Riana Mashar. (2011). No Title Emosi Anak Usia Dini dan Strategi Pengembangannya. Kencana.

Satria, C. T. F. (2019). Utusan IKWI Agam Juara 1 Lomba Manjujai Anak. https:/ / www.topsatu.com/ utusan-ikwi-agam-juara-1-lomba-manjujai-anak/

Sugiyono. (2013). Metode Penelitian Kuantitatif, Kualitatif dan RED. Alfabeta.

Suryana, D. (2016). Stimulasi \& aspek Perkembangan Anak Usia Dini. In Kencana. Kencana.

Taylor, C. R., Lillis, C., LeMone, P., Pamela, L., \& Lebon, M. (2011). Fundamentals Of Nursing: The Art And Science Of Nursing Care. In Lippincott Philadelphia. (7th ed., Vol. 53, Issue 9). Lippincott Philadelphia.

Wardhana, I. G. N. P. (2013). Dalam Keluarga. Jurnal Linguistik, 20(39), 95-101.

Yulia, M. W. (2017, April). Tradisi Manjujai Ransang Pertumbuhan Anak. Harian Haluan. http://www.harianhaluan.com/news/detail/64664/tradisi-manjujai-rangsangpertumbuhan-anak 